\title{
BERPIKIR KRITIS DALAM MENGAMBIL KEPUTUSAN KLINIS
}

\author{
Nabila Salsabila Panggabean / 181101049 \\ E-mail : nabila15salsabila@gmail.com
}

\begin{abstract}
Abstrak
Latar Belakang: Berpikir kritis merupakan perpaduan antara perilaku, pengetahuan dan keterampilan dalam memecahkan dan memberikan kesimpulan sebagai alasan dari permasalahan yang ada. Dalam pengambilan keputusan klinis, berpikir kritis adalah salah satu komponen penting yang digunakan untuk mempertimbangkan tindakan klinis yang akan diambil. Tujuan: Untuk mengetahui pengaruh berpikir kritis dalam pengambilan keputusan klinis yang dilakukan oleh perawat. Metode: Metode kualitatif dengan menggunakan literature berupa buku dan jurnal ilmiah. Hasil: Perawat yang berpikir kritis memiliki peluang 2,760 kali. Pembahasan: Hasil dari penelitian menunjukkan lebih banyak perawat yang berpikir kritis dengan lama kerja $\geq 10$ tahun. Penutup: Ada pengaruh berpikir kritis dalam pengambilan keputusan klinis oleh perawat.
\end{abstract}

Kata kunci : Berpikir Kritis, Keputusan Klinis, Perawat.

\section{Latar Belakang}

Perawat merupakan salah satu komponen vital dalam dunia kesehatan karena perawat yang pertama kali menjalin kontak dengan klien dan yang terlama bersama klien terkhusus untuk klien yang harus dirawat inap dan klien yang harus selalu dipantau. Perawat juga diharapkan memiliki pemikiran yang rasional dan reflektif dalam mengambil keputusan klinis berdasaran pengamatan dan informasi yang dikumpulkan sepanjang proses keperawatan menggunakan kemampuan berpikir kritis yang dimiliki perawat. Berpikir kritis penting untuk dimiliki oleh perawat dalam mengidentifikasi permasalahan klien dan menentukan solusi terbaik untuk mengatasi permasalahan klien (Sumijatun, 2009).

Berpikir kritis merupakan salah satu keterampilan yang harus dikuasai dan ditingkatkan oleh perawat dalam pengambilan keputusan klinis yang berkaitan dengan perawatan klien. Kemampuan berpikir kritis sebelum mengambil keputusan klinis penting dilakukan agar tidak terjadi kesalahan yang tidak diinginkan dalam pemberian asuhan keperawatan. Oleh karena itu, perawat dituntut untuk mengusai serta memperbaharui 
pengetahuannya dan tidak hanya berpatokan menggunakan informasi yang diperoleh dari instansi pendidikan keperawatan atau yang dijelaskan dalam buku. Keterbatasan pengetahuan yang dimiliki perawat dapat menghambat perawat dalam mengambil keputusan mengenai perawatan yang akan diberikan kepada klien yang akan berakibat fatal terhadap klien (Kozier et al, 2010).

Dalam berpikir kritis, kreativitas menjadi komponen utama yang dipadukan dengan pengetahuan perawat dapat menghasilkan suatu solusi baru dan unik untuk masalah yang unik. Kreativitas dalam pengambilan keputusan merupakan kemampuan dalam memecahkan suatu masalah dan mengimplementasikan pemecahan yang lebih baik. Kreativitas dibutuhkan oleh perawat apabila terjadi situasi baru atau saat intervensi tradisional tidak efektif dilakukan terhadap klien. Sebagai contoh, "Arin Palopo, seorang perawat kesehatan anak yang bertugas di rumah untuk merawat Dania yang berusia 9 tahun, yang mengalami ketidakefektifan pernapasan pasca pembedahan abdomen. Dokter memprogramkan spirometer intensif (alat terapi yang meningkatkan ekspansi alveolus). Dania takut terhadap alat tersebut dan mudah lelah selama terapi. Arin memberikan Dania sebuah botol gelembung tiup dan sedotan yang membuat Dania senang. Arin mengetahui bahwa upaya pernapasan pada saat meniup gelembung dapat meningkatkan ekspansi alveolus dan menyarankan agar Dania meniup gelembung di antara terapi spirometer intensif." (Kozier et al, 2010, hlm.334)

Dalam pengambilan keputusan klinis perawat dipengaruhi oleh dua faktor yang meliputi: faktor individu yang termasuk didalamnya mengenai komunikasi baik verbal maupun non-verbal dan faktor lingkungan yang berkaitan dengan tekanan selama bekerja dan otonomi profesional. Faktor individu berfokus pada pembuat keputusan dan properti yang mendukung pemerosesan informasi. Sebaliknya, faktor lingkungan berfokus pada informasi yang akan diproses. Kedua faktor ini saling mempengaruhi dalam pengambilan 
keputusan klinis sehingga tidak mungkin dapat dipisahkan. (Baumgardner, 2018, hlm. 138)

Bouvier-Colle et al (2012) dalam penelitiannya di 25 negara di Eropa mengelompokan penyebab langsung kematian itu yaitu: pendarahan, emboli air ketuban, hipertensi dalam kehamilan, kehamilan ektopik dan aborsi, dan komplikasi anastesi (Alfianur, Susanti, Padillah, \& Purnamasari, 2018, hlm. 161). Selain penyebab langsung, kematian pada ibu hamil dan melahirkan juga diperparah dengan ketidakmampuan berpikir kritis seorang perawat dalam pengambilan keputusan klinis dalam kasus-kasus darurat dan kritis.

Berpikir kritis dapat ditingkatkan dalam lingkungan klinis yang telah diberikan dalam proses pembelajaran untuk mengembangkan pengetahuan dan keterampilan berpikir kritis yang diperoleh secara nyata yang membuat perawat sejak dini telah terdorong untuk melakukan pemecahan masalah menggunakan pengetahuan yang diberikan dalam lingkungan akademik.(Hastuti \& Widiyaningsih, 2017, hlm. 19-20)

\section{Tujuan}

Untuk mengetahui pengaruh berpikir kritis dalam pengambilan keputusan klinis yang dilakukan oleh perawat. Penelitian ini akan memunculkan motivasi untuk meningkatkan kemampuan berpikir kritis pengambilan keputusan klinis, terutama dalam lingkup keperawatan.

\section{Metode}

Metode kualitatif dengan
menggunakan literature yang
berasal dari buku-buku tentang
berpikir kritis dan pengambilan
keputusan klinis, serta beberapa
jurnal.

\section{Hasil}

Berdasarkan penelitian yang dilakukan oleh Deniati, Anugrahwati dan Suminarti (2018, hlm. 22-24), menampilkan analisa univariat, bivariat dan mulivariat. Adapun analisa univariat yang terdiri dari: usia, jenis kelamin, tingkat pendidikan dan lama kerja responden, responden, kemudian distribusi berpikir kritis, tahapantahapan dalam asuhan keperawatan 
dari pengkajian sampai dengan evaluasi serta distribusi asuhan keperawatan. Hasil anaisis disajikan dalam bentuk distribusi frekuensi yang terdiri dari jumlah dan persentase.

Analisis bivariat untuk membuktikan hipotesis penelitian terhadap pengaruh berpikir kritis terhadap kemampuan melakukan asuhan keperawatan dan pengaruh variabel confounding terhadap kemampuan melakukan asuhan keperawatan. responden yang berpikir kritisnya kurang didapatkan distribusi terbesar 23 responden $(62,2 \%)$ dengan kemampuan melakukan asuhan keperawatan kurang. Hasil analisis menunjukkan bahwa ada hubungan antara berpikir kritis dengan kemampuan melakukan asuhan keperawatan $(p=0,026)$. Analisis lebih lanjut menunjukkan bahwa responden dengan kemampuan berpikir kritis baik mempunyai peluang 2,760 kali mampu melakukan asuhan

Tabel 1.

Distribusi, Usia, Jenis Kelamin, Pendidikan, Lama Kerja dan Berfikir Kritis Pada Perawat di Rawat Inap Dengan Asuhan Keperawatan Di Rumah Sakit Hermina Bekasi Juni ( $\mathrm{N}=104)$

\begin{tabular}{|c|c|c|c|c|c|c|c|c|}
\hline \multirow[t]{2}{*}{ Variabel } & \multicolumn{4}{|c|}{ Asuhan Keperawatan } & \multirow{2}{*}{$\begin{array}{c}\text { Total } \\
\mathrm{N}\end{array}$} & \multirow[b]{2}{*}{$\%$} & \multirow[b]{2}{*}{ OR $(95 \% \mathrm{Cl})$} & \multirow{2}{*}{$\begin{array}{c}\text { P } \\
\text { Value }\end{array}$} \\
\hline & Kurang & $\%$ & Baik & $\%$ & & & & \\
\hline \multicolumn{9}{|l|}{ Berfikir Kritis } \\
\hline Kurang & 23 & 62,2 & 14 & 37,8 & 37 & 100 & $2,760(1,205 \cdot 6,321)$ & $0,026^{*}$ \\
\hline Bak & 25 & 37,3 & 42 & 62,7 & 67 & 100 & & \\
\hline \multicolumn{9}{|l|}{ Usia } \\
\hline$<3 B$ tahun & 32 & 45,1 & 39 & 54,9 & 71 & 100 & $0,872(0,381-1,994)$ & 0,909 \\
\hline 238 tahun & 16 & 48,5 & 17 & 51,5 & 33 & 100 & & \\
\hline \multicolumn{9}{|l|}{ Jenis Kelamin } \\
\hline Lakïlaki & 1 & 50 & 1 & 50 & 2 & 100 & $1,170(0,071-19,22)$ & 1,000 \\
\hline Perempuan & 47 & 46,1 & 55 & 53,9 & 102 & 100 & & \\
\hline \multicolumn{9}{|l|}{ Pendidikan } \\
\hline D3 Kep & 43 & 45,7 & 51 & 54,3 & 94 & 100 & $0,843(0,229 \cdot 3,107)$ & 1,000 \\
\hline Sarjana & 5 & 50 & 5 & 50 & 10 & 100 & & \\
\hline \multicolumn{9}{|l|}{ Lama Kerja } \\
\hline$<10$ tahun & 35 & 54,7 & 29 & 45,3 & 64 & 100 & $2,507(1,099 \cdot 5,718)$ & $0,045^{*}$ \\
\hline$\geq 10$ tahun & 13 & 32,5 & 27 & 67,5 & 40 & 100 & & \\
\hline
\end{tabular}

Pada tabel 1. didapatkan bahwa sebanyak 42 responden $(62,7 \%)$ dengan berpikir kritis baik memiliki kemampuan yang baik pula dalam melakukan asuhan keperawatan, sedangkan untuk keperawatan dengan baik dibandingkan dengan responden dengan berpikir kritis kurang Distibusi lama kerja terbesar yaitu $<10$ tahun dengan 35 responden $(54,7 \%)$ memiliki kemampuan 
melakukan asuhan keperawatan kurang, sedangkan responden dengan lama kerja $\geq 10$ tahun distribusi terbesar 27 responden $(67,5 \%)$ memiliki kemampuan melakukan asuhan keperawatan baik. Hasil analisis menunjukkan bahwa ada hubungan antara Lama Kerja dengan kemampuan melakukan asuhan keperawatan (p $<$ 0,05). Analisa lebih lanjut menunjukkan bahwa responden dengan lama kerja $\geq 10$ tahun mempunyai peluang 2,507 kali memiliki kemampuan melakukan asuhan keperawatan dengan baik dibandingkan dengan responden yang lama kerja $<10$ tahun. Tahap selanjutnya adalah analisa multivariate dengan tahapan seleksi kandidat sampai dengan pemodelan akhir.

Pada tabel 2. menunjukkan bahwa $\mathrm{P}$ Value $<0,25$ sehingga variabel berpikir kritis dan lama adalah variabel berpikir kritis dan lama kerja dianalisis dengan uji regresi logistic ganda. Pada pemodelan pertama yang dikeluarkan adalah variabel lama kerja $(p=0,074)$, dari hasil analisis ternyata terjadi perubahan nilai OR setelah variabel lama kerja dikeluarkan yaitu sebesar 14,85\%, karena perubahan OR > $10 \%$ maka lama kerja masuk ke dalam pemodelan akhir. Perawat yang berpikir kritis berpeluang 2,403 kali mampu melakukan asuhan keperawatan dengan baik jika dibandingkan dengan perawat yang kurang berpikir kritis setelah dikontrol oleh lama kerja (CI 95\%: 1,027- 5,622). Perawat yang memiliki lama kerja $\geq 10$ tahun berpeluang 2,144 kali mampu mengambil keputusan klinis dengan baik jika dibandingkan dengan perawat yang lama kerjanya $<10$ tahun setelah dikontrol oleh

Tabel 2. Hasil Seleksi Bivariat Untuk Kandidat Model pada Berfikir Kritis dan Karakteristik Dengan Kemampuan Melakukan Asuhan Keperawatan di RS Hermina Bekasi Periode Juni $2016(\mathrm{~N}=104)$

\begin{tabular}{cl}
\hline Variabel & P Vaive \\
\hline Berfkir Krits & $0,027^{*}$ \\
Lama Kerja & $0,043^{*}$ \\
\hline Variabel dengan a $<0,25$ (kandidat multivariat masuk ketahap selanjutnya) \\
kerja masuk pada tahap pemodelan & berpikir kritis (CI 95\%: 0,917 - \\
multivariate. Tahap berikutnya & $5,015)$.
\end{tabular}




\section{Pembahasan}

Berdasarkan penelitian yang dilakukan oleh Deniati, Anugrahwati dan Suminarti (2018, hlm. 22-24) menunjukkan lebih banyak responden yang merupakan perawat yang telah memiliki keterampilan berpikir kritis daripada perawat yang kurang berpikir kritis. Hasil analisis menunjukkan adanya pengaruh kemampuan perawat dalam berpikir kritis $(\mathrm{p}=0,026)$.

Berdasarkan hasil penelitian ini sesuai dengan teori Perry dan Potter (2010) yang mengatakan bahwa asuhan keperawatan merupakan kegiatan kompleks yang menuntut keterampilan kognitif, psikomotor dan afektif untuk menilai intuitive dan kreatifitas. Dalam melakukan pengambilan keputusan klinis, perawat akan menghadapi bermacam-macam situasi klinis sehingga perawat harus mampu berpikir cerdas dalam setiap situasi yang dihadapinya untuk mampu membuat keputusan yang tepat dan akurat terhadap pengambilan keputusan klinis yang dilakukan kepada pasien.
Berdasarkan hasil analisis peneliti lebih lanjut didapatkan bahwa responden yang berpikir kritis mempunyai peluang 2,760 kali untuk dapat mengambil keputusan klinis dengan baik dibandingkan dengan responden yang kurang berpikir kritis. Berpikir kritis menjadi bagian yang tak terpisahkan dari pengambilan keputusan klinis. Perawat dengan kemampuan berpikir kritis yang baik akan menyadari perannya dan identitas diri dalam kaitannya dengan hal-hal, peristiwa dan orang lain.

$\begin{array}{ccc}\begin{array}{c}\text { Sedangkan } \\ \text { dari }\end{array} & \text { variabel } \\ \text { counfounding } & \text { yang } & \text { dominan }\end{array}$
berpengaruh terhadap kemampuan melakukan asuhan keperawatan adalah lama kerja $(\mathrm{p}=0,045)$, analisa lebih lanjut menunjukkan bahwa responden dengan lama kerja $\geq 10$ tahun mempunyai peluang 2,507 kali untuk dapat melakukan asuhan keperawatan dengan baik dibandingkan dengan responden yang lama kerjanya $<10$ tahun. 


\section{Penutup}

Ada pengaruh berpikir kritis terhadap kemampuan perawat dalam pengambilan keputusan klinis $(\mathrm{p}=0,026)$ daripada perawat yang kurang berpikir kritis dan mempunyai peluang 2,760 kali untuk dapat mengambil keputusan klinis dengan baik dibandingkan dengan responden yang kurang berpikir kritis.

\section{Referensi}

Alfianur. Susanti. Padilah, R, Purnamasari, A. (2018). Gambaran pengambilan keputusan klinis dalam P4K (Program perencanaan persalinan dan pencegahan komplikasi) di daerah pesisir pantai amal lama tarakan. The Journal of Borneo Holistic Health, 1, 160-169.

Baumgarder, D.J. (2018). Uncertainly and competing priorities in shared clinical decision-making. Journal of Patient-Centered Research and Riviews, 5, 137-139.

Croskerry, P,. \& Nimmo, GR. (2011). Better Clinical decision making and reducing diagnostic error. $J R$ Coll Physicians Edinb, 41, 166-162.
Deniati, K,. Anugrahwati, R,. \& Suminarti, T. (2018). Pengaruh berpikir kritis terhadap kemampuan perawat pelaksana dalam melakukan asuhan keperawatan di rumah sakit hermina bekasi tahun 2016. The Journal of Holistic Healthcare, 12, 21-25.

Fathi, A., \& Simamora, R. H. (2019, March). Investigating nurses' coping strategies in their workplace as an incator of quality of nurses' life in Indonesia: a preliminary study. In IOP Conference Series: Earth and Environmental Science (Vol. 248, No. 1, p. 012031). IOP Publishing.

Hastuti, W,. \& Widiyaningsih. (2017). Aplikasi consept mapping dalam pemberian asuhan keperawatan di state maternitas. Jurnal Keperawatan dan Pemikiran Ilmiah, 3, 19-16.

Kozier, B,. et al. (Ed.7). (2010). Buku ajar fundamental keperawatan : konsep, proses dan praktik keperawatan (Eko Karyuni et al, Alih bahasa ). Jakarta: EGC.

Lima, G.P.V,. Pareira, A.L.de F,. Correia, L.M. (2016). In-service teaching of obstetrical nursing residents from perspective of tutorship. 24. 1-11. 2019 , 
http://dx.doi.org/10.5380/ce.v24i0.5997 $\underline{1}$

Nurjanah, S,. \& Wibowo, H. (2014, December 2). Faktor-faktor yang mempengaruhi pengambilan keputusan memilih penolong persalinan pada ibu hamil di desa bangun rejo kecamatan soko kabupaten tuban. 2(2). 31-39.

Patmawat, T.A,. Saleh, A,. Syahrul, S. (2018).Efektifitas Metode Pembelajaran Klinik terhadap kemampuan berpikir kritis dan kepercayaan diri. Jurnal Keperawatan Muhammadiyah, 3, 88-94.

Peixoto, T.A.dos S. M,. \& Peixoto, N.M.dos S.M. (2016, June 30). Critical thingking of nursing students in clinical teaching: an intergrative review. 4(13). 125-138. June 2017 ,
Potter. \& Perry. (2009). Fundamental Keperawatan. Jakarta: EGC.

Sulaiman, A,. \& Syakarofath, N.A. (2018). Berpikir kritis: Mendorong introduksi dan reformulasi konsep dalam psikologi Islam. Buletin Psikologi, 26, 86-96.

Sumijatun. (2009). Manajemen keperawatan konsep dasar dan aplikasi pengambilan keputusan klinis. Jakarta: TIM.

Taylor, C,. et al. (2017, April). The REFER (Refer for echocardiogram) study: a prospective validation and health economic analysis of a clinical decision rule, NT-proBNP or their combination in diagnosis of heart failure in primary case. 3(4). 1-80. April 2017. DOI: 10.3310/eme04030 